\title{
Sokerimaissilajikkeet kuluttajien herkuksi
}

\author{
Marja Kallela \\ Maa- ja elintarviketalouden tutkimuskeskus (MTT) Puutarhatuotanto, Toivonlinnantie 518, \\ 21500 Piikkiö,marja.kallela@mtt.fi
}

\section{Johdanto}

Sokerimaissi on kasvattanut suosiotaan tuoretarjonnan lisääntymisen myötä. Matkoilla alkupaloina tutuiksi tulleet herkulliset maissintähkät ovat tervetullut lisä ruokapöytään. Tähkiä osataan jo odottaa kypsyväksi syyskesällä myös suomalaisten viljelijöiden pelloilta. Sadon vaihtelut maissipelloilla ovat kuitenkin suuria. Myöhäiset lajikkeet eivät ehdi tehdä tähkää, jos kasvukausi on viileä. Sokerimaissin viljely kiinnostaa vaihtelevista kasvukauden oloistamme huolimatta. Parikymmentä vuotta sitten makeat sokerimaissilajikkeet tulivat Eurooppaan. Suomessakin tehtiin iso lajikekoe vuosina 1988-89 kuudellatoista eri lajikkeella (Pessala 1991). Noista ajoista lajikevalikoima on kehittynyt paljon, ja tähkät entistä makeammiksi. Amerikkalaisten ja kanadalaisten lajikkeiden lisäksi on markkinoille tullut kiinnostavia eurooppalaisten jalostajien lajikkeita.

Sokerimaisseja on kolmea eri tyyppiä. Su-lajikkeet ovat vanhimpana tyyppinä menettäneet suosiotaan, koska niiden makeus muuttuu tärkkelykseksi varsin nopeasti tähkän kypsyttyä. Siten niiden korjuu- ja markkinointiaika jää lyhyeksi. Se-lajikkeet ovat korvanneet nämä lajikkeet paremman makunsa ja tasaisemman, kestävämmän laatunsa vuoksi. Tähkien makeus säilyy hieman kauemmin niin pellolla kuin kaupassakin. Kolmas tyyppi on erikoismakea sh2, jonka tähkien sokeripitoisuus on korkea. Tämän tyypin maissilajikkeet suositellaan viljeltäväksi eristettynä muista lajikkeista, jotteivät ne pölyty toisen (su-, se- tai rehutyypin) lajikkeen siitepölyllä. Sh2 -lajikkeiden pölyttyminen toisen lajikkeen siitepölyllä aiheuttaa sen, että sokerin sijasta maissin jyviin varastoituu tärkkelystä eikä toivottua makeaa tähkää kehity. Lisäksi viileys saattaa aiheuttaa ongelmia siementen itämiselle kylmässä maassa. Taimien kasvatus kasvihuoneessa on eduksi makeilla sokerimaissilajikkeilla suorakylvöön verrattuna, koska kevälllä maa on vielä kylmä eivätkä siemenet idä, vaan saattavat mädäntyä.

Tämän tutkimuksen tavoitteena oli etsiä Etelä-Suomen paikallisiin viljelyolosuhteisiin soveltuvia lajikkeita.

\section{Aineisto ja menetelmät}

Lajikekokeissa oli mukana su-, se- ja sh2- tyypin sokerimaisseja. Eri lajiketyyppien lajikkeita ei eristetty toisistaan, koska tarkoituksena oli selvittää lähinnä lajikkeiden ilmastollista menestymistä. Lisäksi eristämistoimenpiteeksi riittää se, että muiden lajiketyyppien siitepölyä ei enää ole ilmassa, kun sh2- lajikkeiden emitähkät puhkeavat kukkaan. Koemallina oli satunnaistettujen lohkojen koe, jossa oli kolme toistoa.

MTT:n vihanneskoepaikalla Kokemäellä peruslannoituksena oli Erikoisviljelyn hivenlannos 300 $\mathrm{kg} \mathrm{ha}^{-1} \mathrm{ja}$ istutuksen yhteydessä Kemiran Puutarhan Y-lannos 3 (NPK: 10-4-17) $700 \mathrm{~kg} \mathrm{ha}^{-1}$. Lisälannoituksena annettiin Suomensalpietaria heinäkuussa (30 kg typpeä hehtaarille). Rikkakasvit harattiin ja kitkettiin kokeista kerran. Kasvihuoneessa kasvatetut noin kolmen viikon ikäiset taimet istutettiin avomaalle Lännen RT2-istutuskoneella. Riviväli oli 50 senttimetriä ja paririvin väliin jätettiin yhden metrin hoitokäytävä. Taimiväli oli 35 senttimetriä. Kastelu tehtiin kastelurampilla. Piikkiössä 2003 rivi oli sama, mutta taimiväli 30 senttimetriä. Maanpinnankatteena oli mustamuovi ja kastelu tehtiin tihkuletkujen kautta. Taimet istutettiin käsin. Peruslannoituksen lisäksi annettiin kalkkisalpietaria ja Puutarhan täyslannosta tihkuletkujen kautta.

Kesä 1999 ei ollut Kokemäellä kovin suosiollinen sokerimaissin viljelylle; juhannuksena ollut rankka ukkosraekuuro palellutti kasvustoja. Halla vei kasvustojen lehdet jo elokuun lopussa. Sokerimaissi on kesken kasvukauden vielä herkempi hallalle kuin taimivaiheessa. Vihanneskoepaikalla oli 23.8.1999 yöllä maanpinnassa $-1,5^{\circ} \mathrm{C}$ pakkasta ja kahden metrin korkeudessa $-0,6{ }^{\circ} \mathrm{C}$. Loppusato ei tuhoutunut tyystin, vaan suurin osa kauppakelpoisesta sadosta kerättiin syyskuun alkupuolella. Viimeiset tähkä kerättiin syyskuun lopussa lämpimän syyskuun takia. Kesä 2002 oli sääoloiltaan hyvä, ja sato saatiin korjattua syyskuun alussa. Piikkiössä kevät 2003 oli vaikea ja kasvuunlähtö hidasta kylmyyden ja liiallisen märkyyden takia. Lämpimän heinä-elokuun aikana 
kasvit kuroivat kiinni menetetyn kasvunsa. Lisäksi tihkukastelun ja kastelulannoituksen avulla kasvu oli voimakasta. Sadonkorjuuseen päästiin 11.8. Syyskuun ensimmäisinä öinä halla vioitti kasvuston lehtiä kuten vuonna 1999, mutta tähkät eivät vioittuneet ja sadonkorjuu lopetettiin syyskuun puoliväliin mennessä.

\section{Tulokset ja tulosten tarkastelu}

'Custer' oli aikaisin sokerimaissilajike joka vuosi. Makeista lajikkeista parhaiten menestyi 'Landmark' ja 'Golda'. Useissa kasveissa oli monta tähkää samassa varressa. Tavallisesti kasvia kohti kasvaa vain yksi tähkä. Kauppakelpoiseen satoon on laskettu täydelliset tähkät ja tähkät, joiden päässä on enintään viisi senttimetriä pölyttymättömiä jyviä (Taulukko 1.). Sato tulokset on laskettu hehtaaria kohden. Epätäydellisiä tähkiä aiheutui eniten vajaapölytteisyyden takia.

Taulukko 1. Sokerimaissin sato lajikekokeissa 1999 ja 2002 MTT:n vihanneskoepaikalla Kokemäellä ja 2003 puutarhatuotannolla Piikkiössä.

\begin{tabular}{|c|c|c|c|}
\hline \multirow[t]{2}{*}{ Lajike } & \multicolumn{3}{|c|}{ Sato $\mathrm{kg} \mathrm{ha}^{-1}$} \\
\hline & 1999 & 2002 & 2003 \\
\hline Custer & 5865 & 5754 & 11245 \\
\hline Wonder & 7496 & & \\
\hline Mecca & 814 & & \\
\hline Patton & 3358 & & 12925 \\
\hline Horizon & 9234 & & 17964 \\
\hline Punchline & 3404 & & \\
\hline Merit & 4615 & & \\
\hline Geronimo & 6540 & 5427 & \\
\hline King Arthur & 5564 & & \\
\hline Arrowhead & 5197 & & \\
\hline Sundance & 7116 & 10095 & 16792 \\
\hline Legend & 9760 & & \\
\hline Sweet wonder & 3067 & & \\
\hline Sunrise & 9747 & & \\
\hline Pinnacle & 4813 & & \\
\hline Landmark & 9029 & 12448 & 15755 \\
\hline Welcome & & 8733 & \\
\hline Golda & & 14354 & 17069 \\
\hline Pronto & & 5730 & \\
\hline Colossal Yellow & & 9479 & \\
\hline Sweet Riser & & 10590 & \\
\hline Tomahawk & & 12022 & \\
\hline Tuxedo & & & 16496 \\
\hline Crystal Cream & & & 14715 \\
\hline First Snow & & & 13268 \\
\hline Early Sweet & & & 15207 \\
\hline
\end{tabular}

\section{Johtopäätökset}

Useita hyviä sokerimaissilajikkeita on tarjolla. Viljelyvarmimpia lajikkeita ovat aikaisin satoa antavat 'Custer', kaksivärinen 'Wonder' ja 'Patton' ja myöhäisemmistä makeista lajikkeista 'Landmark' ja 'Sundance'. Verrannelajike 'Custer' näyttäisi menestyvän hyvin myös viileänä kesänä. 'Horizon' on vanhemmista lajikkeista hyväsatoinen. Etelä-Suomessa sokerimaissin viljely onnistuu hyvin, mutta sadon varmistamiseksi olisi hyvä kasvattaa useampia lajikkeita kasvukausien vaihteluiden takia.

\section{Kirjallisuus}

Pessala, R. 1991.Makeat sokerimaissilajikkeet soveltuvat meillekin. Puutarha 94:208-209. 